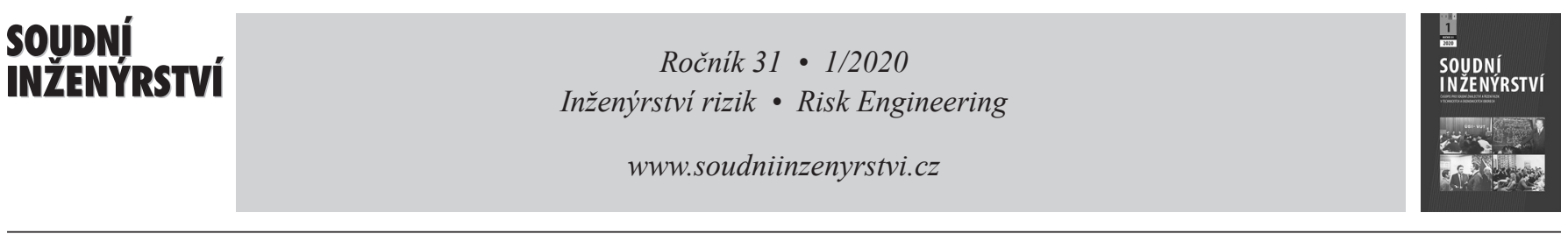

\title{
Souvislosti rizik v dnešní společnosti
}

\section{Interdependencies of Risks in Nowadays Society}

\author{
Jaromír Novák*, Vítězslav Prukner \\ Univerzita Palackého v Olomouci, Fakulta tělesné kultury
}

\begin{abstract}
Abstrakt
Existence dnešní společnosti a její vývojové tendence jsou velmi složité. Rychlé a prudké změny jsou obtížně poznatelné, předvídatelné a tím obtížně řiditelné. Analogicky je složitá problematika prípravy a připravenosti řídích složek všech stupňů řízení až po stupeň člověk, který je rozhodujícím prvkem složitého systému rrízení rizik. Za úspěšné krizové rízení jsou odpovědny nejen orgány krizového rrízení, ale v podstatě všechny řídicí složky. Pod pojmem řízení rizik je nutno si představit vysoce složitý vztah mezi zdroji pro ř́zení rizik, kterými jsou zdroje lidské, finanční, materiální, informační a časové. Má-li být řizení rizik úspěšné, pak musí být vztahy mezi těmito zdroji v optimální proporcionalitě. Příspěvek byl prezentován na Konferenci CRISCON 2019 FLKŘ UTB Zlín v záŕí 2019.
\end{abstract}

Klíčová slova: řízení, krizové řízení, riziko, společnost, systém.

\section{1. ÚVOD}

Dnešní společnost je velmi složitý systém. Toto tvrzení je zpravidla používáno pro charakteristiku každé společnosti. Můžeme se o tom dočítat v různých kronikách, knihách, časopisech a dalších písemných zdrojích. A takřka vždy to nebude tvrzení fádní, ale odpovídající té době, ve které vznikalo. V čem je tedy složitost dnešní doby? Je mnoho příčin. Nelze je všechny vyjmenovat a vlastně ani poznat.

Uved'me jen některé: růst počtu obyvatelstva na planetě a jeho nerovnoměrnost; změna klimatu a z něj vyplývající mnohé problémy; nedostatek potravin, půdy a vody; rozmach informačních technologií všeho druhu; růst množství i kvality prostředků dopravy silniční, železniční, letecké a vodní; rozmach technických prostředků i technologií; násobení moci člověka touto technikou a technologiemi; vyčerpávání zdrojů planety a potřeba zdrojů nových; růst problémů v oblasti mezilidských vztahů mezi

\begin{abstract}
Existence of nowadays society and its Development tendencies are very complicated. Fast changes are hard to recognize, predictable and because of that also hard to manage. Analogically is also very complex the problematics of preparation and readiness of managing parts of all levels of management down to human that is a key part of complex system of management of risks. For successful crisis management are responsible not just organs of crisis management, but also or other managing parts. Under the word risk management is essential to imagine very complex relationship between sources for risks management, that are resources human, financial, material, informational and time. If we want to succeed, these resources must be in optimal proportionality.
\end{abstract}

Keywords: management, crisis management, risk, society, system. jednotlivci, regiony, zeměmi i světadíly; jako problém hlavní je možno uvést obrovský a rychlý růst složitosti existence společnosti a nemožnost či neschopnost řídicích elit tyto problémy poznat a řešit.

\section{MEZINÁRODNÍ VZTAHY JAKO SYSTÉMOVÉ OKOLÍ KRIZOVÉHO ŘÍZENÍ}

Při sledování současných procesů ve světě nás jistě napadá proč k nim dochází a jaké jsou možné př́činy a souvislosti. Odpovědi jsou obtížné, protože historie se opakuje jen zčásti. Protože vývoj je vždy jednotou minulosti, př́itomnosti a budoucnosti, je třeba tyto souvislosti vnímat.

V roce 2020 si budeme připomínat výročí ukončení druhé světové války. Bude to už 75 let, co skončila nejstrašnější válka $\mathrm{v}$ dějinách lidstva. Je zdrojem poučení i pro současnost - pro 
částečné pochopení procesů probíhajících dnes a také směřujících do budoucnosti. Nabízí se alespoň malé prripomenutí.

Každá válka je nesmyslná, přináší mnoho utrpení jak pro ty, kteří ji začnou, tak pro ty, kteří ji skončí. Bývá několik vítězství a k tomu sláva. Více však porážek a tragických důsledků. Celkově lidstvo prohrává. Válka vzniká z nezvládnutého míru.

První světová válka (1914-1918) byla válkou mezi velkými mocnostmi za přerozdělení světa. Některé prohrály, jiné zvítězily. Např́ílad před válkou klesající moc imperiální Británie, se po válce rozšírila. Ovládla oblasti Středního východu a část Afriky. Toto ovládnutí nerespektovalo místní kmenové a etnické zvyky. Bylo provázeno vojenským násilím, zradami, nesplněnými sliby a nepředvídatelnými následky pro miliony lidí, zejména na Středním východě, pro další generace. Tyto následky jsou také zdrojem dnešních konfliktů.

Po dvaceti letech od skončení 1 . světové války začala 2 . světová válka s ještě tragičtějšími důsledky se kterými se rovněž potýkáme dodnes. Paradoxně se Německo a Japonsko, které především rozpoutaly tuto horkou válku a byly v ní poraženy, staly vítězi ve válce studené.

Po dobu posledních let jsme svědky upadajícího vlivu jiného impéria a to Spojených států. USA po desetiletí byly velmocí a supervelmocí. Jenže zákonitosti vývoje jsou neúprosné - jakmile systém vyčerpá možnosti svého rozvoje, začíná upadat a bliží se zániku. Určitými zásahy a opatřeními je možné tento úpadek posunout či velmi radikálními zásahy pak systém oživit. Bude to však už jiný systém. Ekonomika USA je sice velmi silná, ale upadá, morální síla je na tom obdobně. Zatím USA mají obrovskou vojenskou sílu a mají snahu ji využívat (nap̌r. Afgánistán, Irák). USA vedou (ne)promyšlenou kampaň k destabilizaci Ukrajiny a rozšíření NATO až k hranicím Ruska. To nemůže zůstat bez odezvy ze strany Ruska.

USA se svými spojenci budují asijsko-pacifickou sít' vojenských základen k možné konfrontaci s Čínou. Rovněž úpadek vlivu USA v Jižní Americe je zřejmý.

O možné roli USA ve světě píše ve své knize Volba: Globální nadvláda nebo globální vedení, Zbigniew Brzezinsky [1]. Kniha sice vyšla v roce 2004, ale přesto jsou zajímavé některé myšlenky obsažené ve scénářích možných konfliktů (upraveno autorem):

1. Globální a pustošivá strategická válka - je v dnešní době nepravděpodobná, ale možná. Tyto typy válek mohou vzniknou mezi USA a Ruskem či mezi USA a Č́ńnou, nebo mezi Č́nou a Ruskem. Světový mír byl a zatím ještě je udržován relativně rovnovážnou existencí jaderných zbraní mezi Ruskem a USA. Avšak existují i další vlastníci jaderných zbraní, kteří mohou vstoupit do křehké hry války a pozdější vývoj může být nekontrolovaný a nekontrolovatelný, zničující pro celý svět.

2. Významné regionální války, vedené státy s vysoce účinnými zbraněmi. Ohniska možných konfliktů mohou být $\mathrm{v}$ různých regionech a měnit se $\mathrm{v}$ čase $\mathrm{v}$ důsledku neočekávaných příčin.

3. Takzvané třŕštivé etnické střety především v rámci multietnických států.

4. Různé formy národně osvobozeneckých hnutí. Mohou vzniknou v rámci nerovnosti životní úrovně, rasových problémů, problémů hladu, migračních problémů, v rámci tradičních nepřátelství mezi národnostmi a národy.

5. Bleskové výpady jinak slabých států, které dokážou vyrobit zbraně hromadného ničení a najít způsob jejich použití. V posledních letech se uvažuje o možnostech použití biologických zbraní různého typu. Svou roli by mohly sehrát různé epidemie v důsledku migračních procesů.

6. Stále smrtonosnější teroristické útoky proti obzvlášt' nenáviděným cílům, podobné jako 11. září 2001 na Světové obchodní centrum v USA.

7. Ochromující útoky na informační systémy ze strany států, různých zločinných organizací či jednotlivců. Dnes se pro tyto procesy používá pojem kyberterorismus. Je nutno podotknout, že boj s kyberterorismem je velmi složitý a v mnoha př́padech nemožný. Z podstaty věci vyplývá fakt, že aktéři - tedy útočníci budou vždy v předstihu před obránci.

V prostředí České republiky se některé shora uvedené problémy mohou zdát jako vzdálené či nepravděpodobné. Jenže žijeme v éře globalizace a rostoucí vzájemné souvislosti. S tím je v oblasti řízení vưbec a zejména $\mathrm{v}$ oblasti krizového řízení nutně počítat. Je však otázkou, zda jsme či můžeme být na podobné události připraveni.

Diskutuje se na různých úrovních o analogii situace před oběma světovými válkami a připouští se možnost války třetí. Rovněž se hovoří o návratu (a to je ta lepší z horších variant vývoje) ke studené válce.

Co se vlastně děje s prvky systému mezinárodních vztahů? Narůstá počet nestabilních až rozervaných států (Libye, Sýrie, Irák, Ukrajina). Mezinárodní právo je v rozkladu. Mezinárodní organizace jako OSN, EU, OBSE, WTO a další jsou málo funkční. NATO je zatím asi nejlépe fungující organizací, byt' jeho role je do jisté míry sporná.

Tématem posledních let a ne zanedbatelnou hrozbou, jsou problémy migrace. Ani v této oblasti si rrídící struktury světa neví rady. V časopise National Geograpfic [7] (zvláštní číslo 8/2019) píše autor Paul Salopek o svých zkušenostech z migrace. Není to čtení právě radostné. Pohyby lidí na planetě dle archeologických a genetických výzkumů probíhaly zřejmě stále. Lze předpokládat, že tyto pohyby nebyly vždy bezproblémové - asi docházelo ke střetům mezi místními obyvateli a obyvateli přišedšími (viz např́klad Indiáni versus Evropané).

OSN odhaduje, že více než miliarda lidí - každý sedmý člověk (přibližně 14 \%) ze všech dnes žijících lidí - hlasuje nohama, což znamená že se stěhují v rámci své vlasti, nebo překračují hranice. Miliony lidí prchají před nedostatkem jídla, vody, násilím, válkou, pronásledováním, zločinností, politickým chaosem a dalšími problémy. Lidé hledají lepší život. V roce 2017 žilo 258 milionů lidí mimo země svého původu. V uplynulých letech asi $3 \%$ světové populace tvoří migranti.

Objevují se noví aktéři světového dění, někdy obtížně identifikovatelní. Historické země, tzv. vyspělé, se chovají neobvykle, porušují dlouhodobě zažité spojenecké vztahy. Roste počet konfliktů, v nichž umírají civilisté. Silně roste sociálního napětí a nepokoje uvnitř států i mezi nimi.

V čem jsou příčiny současného světového chaotického vývoje, které hybné síly za tím stojí a jaké mohou být důsledky, je možná problém pro Delfskou věštírnu. Neznáme-li přičiny, není pak možno problémy poznat a také řídit.

\section{OBLASTI RIZIK ŽIVOTA PRO VŠECHNY}

Svět, a v rámci něj jako důsledek globalizačních procesů i Česká republika, se nachází v dlouhé řadě rizik, které se prohlubují 
a mohou vyústit do nebezpečných důsledků. Můžeme je nazvat jako [4]:

- rizika životních hodnost,

- mezilidská rizika,

- finanční rizika,

- hospodářská rizika,

- potravinová rizika,

- vodní rizika - pitná voda, povrchová voda, oceány,

- zemědělská rizika,

- půdní rizika,

- zdravotní rizika

- politická rizika,

- surovinová rizika,

- energetická rizika,

- informační rizika,

- dezinformační rizika,

- kybernetická rizika

- sociálně-kulturní rizika,

- rizika řízení.

Tato rizika probíhají současně, úzce spolu souvisejí a vzájemně se ovlivňují. Není jednoduché je rozpoznat, odhalit všechny příčiny a souvislosti. Je obtížné je popsat, nacházet řešení a nějakým způsobem je adekvátně řídit. Jsou to velmi složité systémy s vysoce stochastickým chováním. Projevy a důsledky rizik a z nich vyplývajících krizí jsou těžko předvídatelné. Mění se $\mathrm{v}$ čase a prostoru. Jsou komplexní i komplexitní.

$\mathrm{Z}$ hlediska prostorového rozmachu príčin a důsledků krizí lze $\mathrm{v}$ zásadě očekávat jednotu i rozpornost. Jejich podstata bude stejná, ale jejich konkrétní projevy jiné. Jednotlivé krize, či komplex krizí, má své globální i regionální příčiny i důsledky, obsah a rozsah. Regiony se však budou lišit dle konkrétních podmínek.

Nebezpečnost se projevuje zejména svými hrozbami, riziky a z nich vyplývajícími konkrétními situacemi.

Při přípravě institucí různého typu je třeba vycházet $\mathrm{z}$ tzv. krizových zákonů, bezpečnostních strategií různého typu, koncepcí ochrany obyvatelstva a dalších norem. Nutno podotknout, že ne vždy jsou tyto normy dodržovány. Další poznámka směřje k odpovědnosti občana. $Z$ výše uvedených norem vyplývají jisté povinnosti, které je nutno dodržovat. Bylo by jistě užitečné a prospěšné, kdyby se občan o tyto povinnosti zajímal a věděl, co má konat. Měl svůj „krizový a havarijní plán“. To je ale dost nepravděpodobné z mnoha př́íčin. Jako hlavní příčinu autor vidí v nezájmu či nechuti občanů normy dodržovat. A také je to nákladné.

Síla a zároveň slabost dnešního člověka je ovlivňována zejména technikou a technologiemi. A ty se musí řídit nejen určením jejich použití a ziskem výrobců a uživatelů, ale také výchovou i výcvikem, jak tuto techniku a technologie používat z hlediska působení na člověka a životní prostředí ve svých důsledcích. To také souvisí s obecným chováním a jednáním člověka a $\mathrm{k}$ tomu je třeba jej odmalička vychovávat. Je to jedna z cest snižování nebezpečnosti a rizikovosti. Člověk je svojí podstatou stejný, jen jeho myšlení a jeho jednání je jiné, je modifikováno novými informacemi a novými podmínkami, které ho obklopují.

Trochu nedávné historie. Na přelomu devadesátých let minulého století došlo $\mathrm{k}$ historickému přerodu. $\mathrm{Z}$ řady vnitřních i vnějších příčin došlo ve dřivějších socialistických státech Evropy k radikálnímu společenskému a ekonomickému převratu. Mezi socialistické státy patřily zejména Bulharsko, Československo, Mad'arsko, Polsko, Rumunsko, Sovětský svaz. Tyto země tvořily Radu vzájemné hospodářské pomoci, což bylo ekonomické uskupení. Tvořily také obranné politicko-vojenské uskupení nazývané Varšavská smlouva. Došlo k rozpadu obou organizací.

Śírila se euforie o míru, svobodě, demokracii, lidských právech, o lásce a pravdě, o rychlém ekonomickém rozvoji. Lidé očekávali, že bude mír a budou se mít lépe, že svět bude bezpečnější. Postupně, v průběhu tř́ desetiletí, se ukazuje, že to byla manipulace a lidé se cítí podvedeni. Cítí jistou beznaděj, marnost, bezvýchodnost. Jsou to nebezpečné kombinace potenciálních škodlivých jevů a procesů.

Po desetitisíce let se člověk, jako intelektuálně nejvyšší bytost planety snaží žít a přežít, motivován mnoha nutnostmi i touhami. Je hnán dopředu, odstraňuje rozpory mezi potřebami a možnostmi a vytváří podmínky pro své žití. Má touhu a potřebu seberealizace. Chce tvořit, ale také ničit.

Člověk buduje své obyčejné žití i svět kolem sebe a někdy si připadá jako bájný Sisyfos. Jeho potřeba žít v míru s okolím a v bezpečí je narušována či dokonce negována násilím.

Násilí a konflikty pravděpodobně vždy byly nedílnou součástí života jednotlivce a společnosti. Vyplývá to z podstaty člověka a objektivních podmínek jeho existence. Člověk k přežití potřebuje objektivně i jistou míru násilí a se vznikem státu toto násilí získává i zákonnou formu. Stává se legální.

Násilí souvisí s krizovým řízením. Jednak je nutné někdy přijmout metody a prostředky krizového řízení jako řešení následků násilí. Násilné metody je nutné používat při řešení krizových situací, jako nástroj řešení krize. Vrcholným projevem násilí je válka, kdy agresor používá všech násilných prostř̌edků k uskutečnění svých dobyvačných cílů. Bránící se strana pak musí použít stejného násilí k obraně svých práv.

Je prokazatelné, že kvantitativně i kvalitativně dochází k růstu násilí. Zde je vhodné si připomenout Ericha Fromma, který definuje násilí jakožto důsledek nežitého a zmrzačeného života a to důsledek nutný. Člověk, který nemůže tvořit, musí ničit. Jsme svědky rostoucího ničení. Násilí má spoustu forem a podob - lidské (tělesné i duševní), vojenské, ekonomické, finanční, politické apod. Rozdíl mezi válkou a mírem je dnes stále méně patrný. Technické vybavení pro různé druhy násilí se nesmírně rozrostlo co do kvality i kvantity. Pocit bezpečí se u lidí snižuje a působí negativně na zdraví duševní, tělesné i sociální.

Dalším rizikovým faktorem je rostoucí nejistota a beznaděj z budoucnosti. Společnost nemá vizi důstojnou člověka, nemá pozitivní předpovědi. Informace, které člověk o světě dostává, jsou převážně negativní a také negativně působí na zdraví tělesné, duševní i sociální. Člověk je jen nepatrnou částkou reality.

Část společnosti se rozhořčuje nad zločiny, ale není schopna je vykořenit, ba naopak mocenské elity politické i ekonomické samy vytvářejí pro ně podmínky.

Roste monopolizace hybných sil dneška a zítřka - ekonomika, technika, technologie, informace, politika, vojenská síla. Část hybných velmocenských sil se snaží o světovládu. Tržní mechanismy selhávají. V této snaze o monopolizaci a o růst moci je skryt zárodek budoucí velké destrukce.

Hlavní charakteristické rysy dnešní i budoucí doby a možná lze říci, že i principy existence, jsou: 
1. Nezvládnuté řízení člověkem, násobené silou techniky a technologií.

2. Nezvládnuté předvídání důsledků rozhodování.

3. Nepř́znivé důsledky rozhodování.

4. Rezignace na nepř́íznivé důsledky rozhodování.

Sledujeme-li každodenní události, k nimž ve světě dochází a vývoj světa vůbec, pak znepokojení je nutné. Zřejmá neschopnost, bezradnost, lživost, vyhýbání se odpovědnému řešení problémů ze strany řídících struktur je znepokojující. Stejně tak masová manipulace s lidmi. Co se bude dít dál? Těžko odpovědět. Doufejme, že vývoj bude obecně prospěšný.

Za hlavní rozpor dnešní doby je možno považovat rozpor mezi množstvím informací a schopností člověka je transformovat do produkce, která přináší přidanou hodnotu v nejširším smyslu slova.

\section{ZÁVĚR}

V př́spěvku jsou vyjádřeny jen některé problémy, kterými je nutné se zabývat. Problémů vyžadujících řešení je mnoho, komplexita našeho bytí je velká, ještě větší je varieta možností směřování věcí, jevů a procesů kolem nás a v nás. Jako jeden $\mathrm{z}$ nejtěžších úkolů před každým z nás stojí nutnost adekvátního řízení. Především svého života, nebot' ten je rozhodující determinantou našeho konání. Autor si je vědom jejich nesmírné složitosti, rozpornosti, a také důležitosti a potřebnosti jejich řešení, má-li být vývoj společnosti uspokojivý. Jednoduchá vyjádření v článku mají mít motivační účinek k přemýšlení a zejména jednání.

Autor se nechal inspirovat literaturou, která byla vydaná před několika lety a stále je aktuální i pro současné problémy společnosti.

Sdělené problémy $\mathrm{v}$ tomto článku mohou být respektovány i v oblasti soudního inženýrství jako multispektrální okolí i s možností odrazu v zákonech či jiných normách.
Jak se bude dařit řešení hlavního rozporu dnešní doby - rozpor mezi množstvím informací a schopností člověka je transformovat do produkce, která přináší přidanou hodnotu v nejširším smyslu slova, taková bude i budoucnost. O tom se rozhoduje dnes a doufejme, že není př́liš pozdě, protože zřejmě nejsme dost dobře připraveni ani na současnost, natož pak na budoucnost. Autor chce varovat a tak malým dílem přispět $\mathrm{k}$ potenciálu opravdového optimismu v budoucnosti.

Článek není radostný. Dovolím si na závěr závěru jedno gruzínské př́ísloví: „Ještě nebylo noci, aby po ní nepřišel den“.

\section{LITERATURA}

[1] BRZEZINSKI, Z. Volba: globální nadvláda nebo globálni vedení. Mladá fronta, Praha, 2004. ISBN 80-204-1179-8.

[2] FISCHEL, M. a kol. Rozpravy o řízení. Naše vojsko, Praha, 1996. ISBN 80-206-0514-2.

[3] JIRÁSEK, J. Agenda př̌štich let. Professional publishing, Praha, 2006. ISBN 80-86946-04-5.

[4] NOVÁK, J. Aktuální problémy bezpečnosti. Podniková ekonomika a manažment, mimořádné čislo, Medzinárodná vedecká konferencia „,Globalizácia a jej sociálno-ekonomické dósledky „,11“, Žilinská univerzita, Žilina, 2011.

[5] POTÚČEK, M. a kol. Jak jsme na tom. A co dál? SLON, Praha, 2005. ISBN 80-86429-45-8.

[6] RIFKIN, J. Evropský sen. Evropský literární klub, Praha. ISBN 80-6316-62-9.

[7] SALOPEK, P. Putování s migranty. National Geographic 8-2019, VLTAVA LABE MEDIA, Praha, 2019. ISSN 1213-9394.

[8] KONEČNÝ, J. Krizové ř́zeni a řešeni krizových situací. Univerzita Tomáše Bati ve Zlíně, Zlín, 2019. ISBN 978-80-7454-875-8.

\section{Správná citace:}

NOVÁK, J., PRUKNER, V. Souvislosti rizik v dnešní společnosti. Soudní inženýrství, 2020, 31(1), 31-34.

DOI: http://dx.doi.org./10.13164/SI.2020.1.31. ISSN 1211-443X. 